\title{
TROPHIC ECOLOGY OF THE BLOTCHED STINGRAY, UROTRYGON CHILENSIS (ELASMOBRANCHII: MYLIOBATIFORMES: UROTRYGONIDAE), IN THREE AREAS OF THE MEXICAN PACIFIC
}

\author{
Erick C. OÑATE-GONZÁLEZ1 , Felipe AMEZCUA ${ }^{1 *}$, John BUSZKIEWICZ², \\ Alba Lucía CASTELLANOS-CENDALES ${ }^{3}$, and Felipe AMEZCUA-LINARES ${ }^{4}$ \\ ${ }^{1}$ Instituto de Ciencias del Mar y Limnología, Universidad Nacional Autónoma de México, Mazatlán, Sin., México \\ ${ }^{2}$ Marquette Biological Station, US Fish and Wildlife Service, Marquette, MI, USA \\ ${ }^{3}$ Posgrado en Ciencias del Mar y Limnología, Universidad Nacional Autónoma de México, Ciudad de México, México \\ ${ }^{4}$ Instituto de Ciencias del Mar y Limnología, Universidad Nacional Autónoma de México, Ciudad de México, México
}

Oñate-González E.C., Amezcua F., Buszkiewicz J., Castellanos-Cendales A.L., Amezcua-Linares F. 2017. Trophic ecology of the blotched stingray, Urotrygon chilensis (Elasmobranchii: Myliobatiformes: Urotrygonidae), in three areas of the Mexican Pacific. Acta Ichthyol. Piscat. 47 (2): 185-196.

Background. There is a current global consensus that to achieve a sustainable use of fisheries resources, management of every organism subject to exploitation is required rather than only those targeted directly by the fisheries. Further understanding the feeding habits of the species in the ecosystem as well as the predator-prey relationships and their trophic levels is crucial. Batoids occupy an important ecological niche as benthic predators in estuaries and bays. There is no directed fishery for the blotched stingray, Urotrygon chilensis (Günther, 1872), but it is commonly caught incidentally by trawl and bottom gillnets fisheries subsequently diminishing its population. Recently, artisanal fisheries in Mexico have become focused on batoid species due to the depletion of shark catches, although there are few studies on its biology and ecology.

Materials and methods. We analysed the trophic ecology of the blotched stingray in two main areas from the Mexican Central Pacific to understand the species' diet and detect possible differences throughout fishing areas using stomach content analysis. We analysed the overlap in diets between areas and the trophic level at each area. Results. We analysed 423 specimens and found 15 prey groups. Representatives of the two crustacean higher taxa-Cladocera and Peracarida were the most important food items in the north area, while the crustacean family Penaeidae was the most important in the south area, having no significant overlap between areas $(C \lambda=0.33)$. The estimated trophic position for the blotched stingray was 3.51-3.56 in both areas, and according to the Levin's index, the range of the trophic niche breadth for the blotched stingray was 0.059 and 0.039 , which indicates that it is a specialist predator.

Conclusion. The blotched stingray is a specialist predator that can adapt to different prey depending on which organisms are present in the ecosystem. It is necessary to continue with these types of studies for the other species inhabiting the area, in addition to monitoring fisheries landings, fishing effort, and variations in biotic and abiotic factors in the area over a long period. However, this study outlines an approach for reaching the ultimate goal of sustainable exploitation of marine resources on an ecosystem level.

Keywords: stomach content analysis, stable isotopes analysis, trophic position, small scale fisheries

\section{INTRODUCTION}

The majority of the exploited fish species in estuaries, lagoons, and coastal areas of tropical and subtropical regions lack management programs and regulations, and when these exist, they are still developed within the realm of population ecology (Quinn 2003, Mangel and Levin 2005), utilizing single species population dynamics models as core tools in the stock-assessment process. However, there is a current global consensus that to achieve a sustainable use of fisheries resources, management of every organism subject to exploitation is required rather than only those targeted directly by the fisheries (Koen-Alonso 2007). Therefore, a shift is needed from the traditional single-species focus to a more holistic approach toward utilization of aquatic resources while maintaining fully functional ecosystems (Clark et al. 2001, Marasco et al. 2007). 
Considering the current overexploitation of marine resources and the rapid degradation of ecosystem integrity, the newest approach for managing fisheries is on the ecosystem scale, with an Ecosystem-Based Fisheries Management (EBFM). Thus far, the primary tool used for fisheries regulation is a stock approach which does not account for the trophic network linking marine ecological components. However, it is recognized that for an EBFM approach, it is necessary to analyse the aquatic ecological networks and the related impacts of the fishery. Therefore, understanding the feeding habits of the species in the ecosystem as well as the predator-prey relationships and their trophic levels is crucial (Colléter et al. 2013). Under this new perspective, trophodynamic models now address the joint dynamics of fisheries resources. Fish trophic position $\left(T_{\mathrm{p}}\right)$ is currently recognized as a useful indicator of human disturbance, and trends in the mean $T_{\mathrm{p}}$ values of fishery landings are often used as a sustainability and marine biodiversity indicator (Pauly and Watson 2005, Branch et al. 2010).

Studies of feeding habits and diet, aspects of the biology and ecology (Bethea et al. 2004, Marshall et al. 2008, Jacobsen and Bennett 2012, Rogers et al. 2012, Tillett et al. 2014), trophic position of elasmobranchs, and their intra-interspecific relations (Wetherbee and Cortés 2004, Jacobsen and Bennett 2012) are key to understanding the use of energetic resources in an ecosystem. Such studies provide basic biological knowledge of the trophic dynamics of a community and contribute to the evaluation of the energy flow in the ecosystem, which are important tools for describing and understanding the structure of an ecosystem.

Batoids are cartilaginous fishes represented by rays, skates, and manta rays (Cailliet et al. 1986). There are approximately 450 species described, which were recently reclassified within four orders: Rhinopristiformes, Rajiformes, Torpediniformes, and Myliobatiformes (Eschmeyer et al. 2017). Within the Myliobatiformes, the Urotrygonidae (round rays) is a family characterized by a well-developed caudal fin, the outer anterior margin of pectorals are continuous alongside of head, and most species show one or more long poisonous spines on tail. Round rays are mainly found in lagoons and estuaries (McEachran and Miyake 1986, Platell et al. 1998), and the majority of them are benthic and live in soft soils of estuaries and bays (McEachran and Carvalho 2002), within tropical and temperate waters (Fischer et al. 1995). Although most batoids feed on similar prey species, the food categories can be considerably different between species and even between conspecifics, having sex or size-biased differences in feeding behaviour (Platell et al. 1998). These ontogenetic changes are important for understanding the ecology of batoids (Werner and Gilliam 1984) as they are directly related to changes in habitat use, energy requirements, and trophic interactions (Smale and Cowley 1992, Marshall et al. 2008, Jacobsen and Bennett 2012).

Particularly, the blotched stingray, Urotrygon chilensis (Günther, 1872), is distributed from the Gulf of California to Chile (McEachran and Carvalho 2002). It has a subrhombic disc, which is wider than long, having straight anterior margins, and rounded lateral and posterior margins that cover half of pelvic fins. Their eyes and spiracles are the same size, and spines are present along the body up to the tail, which is longer than the disc (McEachran and Miyake 1986, Amezcua-Linares 1996).

This species, like other rays and sharks, are highly vulnerable to fishing mortality based on its life history characteristics which include: low fecundity, long lifespan, and gestation period, low growth rate, complex spatial structure in a size and sex-biased segregation, and a narrow stock-recruit ratio (Pratt and Cassey 1990, Bonfil 1994, Bonfil 1997). Although there is no directed fishery for this species, it is commonly caught incidentally by trawl and bottom gillnet fisheries subsequently diminishing its population (Andrew and Pepperell 1992, Dulvy and Reynolds 2002, McEachran and Carvalho 2002, Fischer et al. 2012, Dulvy et al. 2014), and recently, artisanal fisheries in Mexico have become focused on batoid species due to the depletion of shark catches. Since the blotched stingray is a predator, the removal of this species from an ecosystem may affect multiple trophic interactions, thus changing the community composition (Stevens et al. 2000).

In order to understand the trophic ecology of elasmobranch species, stomach content studies have been widely used to evaluate the feeding habits of the primary commercial species like Pacific angel shark, Squatina californica Ayres, 1859; Haller's round ray, Urolophus halleri Cooper, 1863; Munda round ray, Urotrygon munda Gill, 1863; thorny stingray, Urotrygon rogersi (Jordan et Starks, 1895); Panamic stingray, Urotrygon aspidura (Jordan et Gilbert, 1882); dwarf stingray, Urotrygon nana Miyake et McEachran, 1988; big skate, Raja binoculata Girard, 1855; California skate, Raja inornata Jordan et Gilbert, 1881; longnose skate, Raja rhina Jordan et Gilbert, 1880; sandpaper skate, Bathyraja interrupta (Gill et Townsend, 1897); diamond stingray, Dasyatis dipterura (Jordan et Gilbert, 1880); Pacific cownose ray, Rhinoptera steindachneri Evermann et Jenkins, 1891; and speckled guitarfish, Rhinobatos glaucostigma Jordan et Gilbert, 1883 (see Cortés 1997, Escobar-Sánchez et al. 2006, Bizzarro et al. 2007, Flores-Ortega et al. 2011, NavarroGonzález et al. 2012).

In the presently reported study, we analysed variations in the diet of the blotched stingray in three Mexican states adjacent to the Pacific Ocean to better understand the species' feeding habits, and detect sexual, temporal, and spatial differences through the analysis of the prey items from stomach content analysis (SCA) and stable isotopes analysis (SIA). The SCA provides information relevant to the taxonomic and size composition of diets and clarifies predator-prey interactions in complex ecosystems where species have diverse consumption patterns which are difficult to identify from other studies (Layman et al. 2005), while SIA determines the food sources, and the trophic position of the organisms (Levine 1980, Benke et al. 2001). 


\section{MATERIAL AND METHODS}

Blotched stingrays, Urotrygon chilensis, were collected along the Mexican Pacific states of Sinaloa, Michoacán, and Guerrero (Fig. 1). The specimens were obtained from the commercial landings, as well as demersal fish surveys on a research vessel, using a shrimp trawl net with mesh sizes of $3.9-5.08 \mathrm{~cm}$, a bolt-rope of $240 \mathrm{~cm}$ in a 30 min of duration at a speed of 2 to 2.5 knots. At Sinaloa, sampling occurred during 2006 (March, May-July, November-December) and 2007 (April-June, August) and all the specimens come from the commercial catch. At Michoacán, sampling occurred during 2003 (January), 2005 (September), 2008 (April), and 2009 (August). At Guerrero, sampling was completed during 2002 (February and May), 2003 (January), 2005 (September), 2008 (April), 2009 (August), 2010 (February, April, June, August, October), and 2011 (February). In Michoacán and Guerrero all the samples from 2002 to 2008 were obtained from surveys; the rest were obtained from the commercial catch. The samples from the surveys were frozen and transported to the laboratory (with a maximum time of three hours of transportation) for posterior analysis. The samples from the commercial catch were processed in situ, and the stomachs were fixed in $4 \%$ formalin to stop the digestion process.

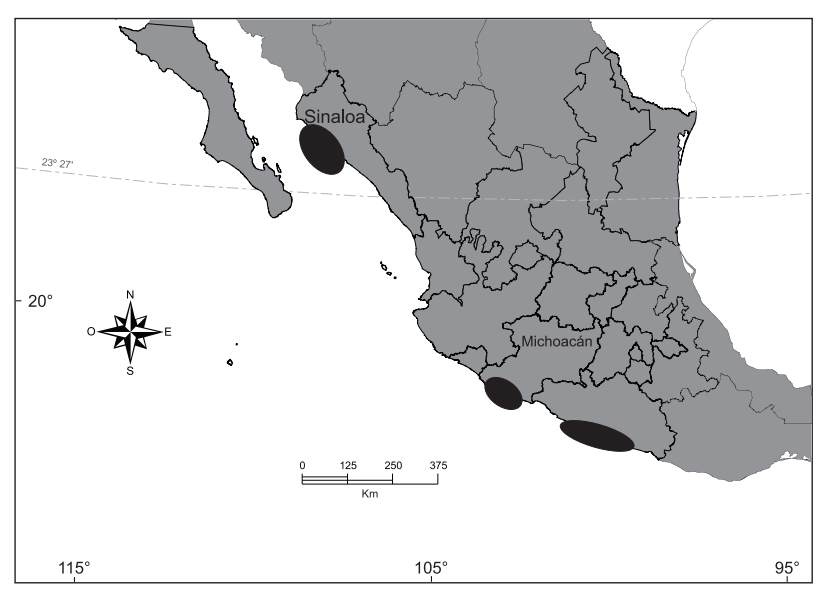

Fig. 1. Map showing sampled regions; The north region included Sinaloa state, and the south region included Michoacan and Guerrero states (Mexican Pacific)

In the laboratory total length $( \pm 1 \mathrm{~mm})$, weight $( \pm 0.05 \mathrm{~g})$, and sex of specimens collected on surveys were recorded; the total length and weight of the specimens sampled at the commercial catch was not available, so a size-biased analysis was not attempted. All organisms were dissected; stomachs were removed and preserved in $4 \%$ formalin to determine which recently consumed prey items were present. Stomach contents were identified under a Leica S4-E stereo microscope. Prey items were identified to species whenever possible; however, due to partial digestion, prey items were typically identified to family or the lowest taxonomic level possible based on specialized identification guides (Gosner 1971, Nelson 1984, Schram 1986, Salazar-Vallejo et al. 1988, Hendrickx 1995, Smith and Johnson 1996). Diet items were counted and weighed to the nearest milligram after being dried by an oven to remove surface water. For analyses, prey items were divided into groups similar to those used by Jacobsen and Bennett (2013), which consider the taxonomy of various prey items as well as their life history traits (e.g., mobility, size, and morphological relations).

If items were too digested to be counted but still recognizable as belonging to a large taxonomic group, they were described as 'remains' of this category, and were weighed together. If prey items were not whole or nearly whole, numbers were based on countable parts, such as claws and legs for crustaceans, otoliths for fishes, and beaks for cephalopods (Ellis and Musick 2007).

Randomized cumulative prey curves were constructed per each region (Sinaloa, Michoacán, and Guerrero) using the Michaelis-Menten equation to determine whether the sample size was adequate to describe the diet of the blotched stingray. When a cumulative prey curve trends toward an asymptote, the number of stomachs analysed is considered sufficient in describing dietary habits of the predator studied, and the asymptote of the curve indicates the minimum sample size required to describe the diet adequately (Ferry and Cailliet 1996). The form of this equation is:

$$
S_{(n)}=\frac{S_{\max } n}{B+n}
$$

where $S(n)$ is the number of species observed in n samples; $S_{\max }$ is the total number of species in the assemblage and $B$ is the sampling effort required to detect $50 \%$ of $S_{\max }$. The samples were randomized 1000 times on Microsoft Excel.

In order to determine the effect of the abiotic factors (zone, sex, climatic season, and year) on dietary items, multivariate analyses were employed. The data were arranged into a matrix comprising the weight $[\mathrm{g}]$ of each prey item, and each stomach was labelled with the fishing region (Sinaloa, Michoacán, and Guerrero), the sex, year, and season. The data were fourth-root transformed to reduce the effect of very abundant prey on the analysis while retaining the quantitative nature of the data. All data were standardized to the percentage of total biomass accounted for each species, to eliminate the effect of differing sample size. Rare prey items (constituting less than $4 \%$ in any sample) were removed. Ordination nonmetric multidimensional scaling (nMDS) analyses were applied to Bray-Curtis similarity indices between pairs of samples to determine groups according to the factors. To check for statistical evidence that species composition of diets differed between the analysed factors, an analysis of similarity multivariate (ANOSIM) permutation test was employed using R-statistic values for pair-wise comparisons to determine the degree of dissimilarity between groups (Clarke and Warwick 2001). If differences were found, a SIMPER (similarity percentages) was used to determine which prey categories accounted for most of the dissimilarities within and between the levels of the tested factor when they were significantly different 
(Clarke and Warwick 2001). All analyses were performed using PRIMER 6 software.

For each group of prey, $\% N, \% W$, and $\% F$ were estimated according to sex and locality; $\% \mathrm{~N}$ and $\% \mathrm{~W}$ represent the food items' quantities and wet weights respectively, whilst $\% F$ is the frequency of occurrence of each food item (presence-absence) in all stomachs that contained food, as described by Pinkas et al. (1971) and Preti et al. (2004). The contribution of each prey (dietary item) to the diet was estimated using the index of relative importance (IRI) calculated for every region as:

IRI $=(\% N+\% W) \times(\% F)$

Additionally, IRI was subsequently modified as a percentage after Cortés (1997).

To examine dietary similarities between the factors statistically influencing dissimilarities in the diet composition of the blotched stingray, we use the MorisitaHorn index $(C \lambda)$ (Smith and Zaret 1982):

$$
C \lambda=\frac{2 \sum_{i=1}^{n}\left(P_{x i} \times P_{y i}\right)}{\left(\sum_{i=1}^{n} P_{x i}^{2}+\sum_{i=1}^{s} P_{y i}^{2}\right)}
$$

where $P_{x i}=$ proportion of prey $i$ over all prey consumed at the factor $x, P_{y i}=$ proportion of prey $i$ over all prey consumed at the factor $y, n$ and $s=$ total number of prey. This index varies between 0 and 1 , and it is considered as a biologically significant overlap if the value exceeds 0.6 (Langton 1982).

The fish trophic position $T_{\mathrm{p}}$ for blotched stingray was estimated using 2 methods, first trough stomach content values with the following equation proposed by Cortés (1999) and Ebert and Bizzarro (2007):

$$
T_{p}=1-\left(\sum_{j=1}^{11} P_{j} T_{P P}\right)
$$

where $T_{\mathrm{PP}}$ is the trophic level of the prey category, $j$ and $P_{j}$ are the contributions each prey category made to the diet of each species (Jacobsen and Bennett 2013) and $P_{j}$ was based on IRI.

The $T_{\mathrm{p}}$ was also estimated from $\delta^{13} \mathrm{C}$ and $\delta^{15} \mathrm{~N}$ isotopes. For this, muscle tissue of three individuals per sex and its respective locality $(n=18)$, were lyophilized at $-45^{\circ} \mathrm{C}$ for three days, and pulverized to a homogeneous powder with an agate mortar. The samples were then transferred to plastic containers and stored until analysis. Samples for $\delta^{13} \mathrm{C}$ analysis were treated with acid prior to isotopic analysis ( $\mathrm{HCl}$ vapours for four hours within a glass desiccator). Aliquots were weighed, pressed into tin capsules (Costech, Valencia, CA), and sent to the Stable Isotope Facility at the University of California, Davis for determination of stable isotope ratios $\left({ }^{13} \mathrm{C} \div{ }^{12} \mathrm{C}\right.$ and $\left.{ }^{15} \mathrm{~N} \div{ }^{14} \mathrm{~N}\right)$. Analyses of stable isotope composition used a PDZ Europa ANCA-GSL elemental analyser interfaced to a PDZ Europa 20-20 isotope ratio mass spectrometer (Sercon Ltd., Cheshire, UK). Results are reported as parts per thousand (\%o) differences from a corresponding standard:

$$
\delta \mathrm{X}=\left[\left(\frac{R_{\text {sample }}}{R_{\text {standard }}}\right)-1\right] \times 10^{3}
$$

where $\mathrm{R}={ }^{15} \mathrm{~N} \div{ }^{14} \mathrm{~N}$ or ${ }^{13} \mathrm{C} \div{ }^{12} \mathrm{C}$. The standards were Carbon in the PeeDee Belemnite and Nitrogen in the air. The analytical precision of these measurements was $0.2 \%$ for $\delta^{13} \mathrm{C}$ and $0.3 \%$ for $\delta^{15} \mathrm{~N}$.

The $T_{\mathrm{p}}$ was estimated using both values of $\mathrm{N}$ and $\mathrm{C}$ isotopes according to the equation proposed by Post (2002):

$$
T_{p}=\frac{\lambda+\left[\delta^{15} \mathrm{~N}_{\mathrm{sC}}-\left(\delta^{15} \mathrm{~N}_{\text {base }} \times \alpha+\delta^{15} \mathrm{~N}_{\text {base } 2} \times(1-\alpha)\right)\right]}{\Delta_{n}}
$$

where $\lambda$ is the trophic level of the base of the food web, $\delta^{15} \mathrm{~N}_{\mathrm{SC}}$ is the nitrogen signature of the species of the consumer being evaluated, $\mathrm{F}$ is the fractionation of $\mathrm{N}$ between each trophic level and $\delta$ is the proportion of nitrogen in the consumer, ultimately derived from the base of food web one. When the movement of $\mathrm{N}$ and $\mathrm{C}$ through the food web is similar, $\delta$ can be estimated using carbon isotopes such that:

$$
\alpha=\frac{\delta^{13} \mathrm{C}_{\mathrm{sC}}-\delta^{13} \mathrm{C}_{\text {base } 2}}{\delta^{13} \mathrm{C}_{\text {base } 1}-\delta^{13} \mathrm{C}_{\text {base } 2}}
$$

In this study, we considered the source of estuarine nutrients as the base 1 , which is constituted by phytoplankton, seston (defined as a mix of phytoplankton and suspended organic matter), detritus (comprised of living organisms and plants present in the sediment), and benthic macroalgae. Considering the relative proportions of primary producers to detritus and seston, the average $\delta^{15} \mathrm{~N}$ value was calculated for the base of the food web in the previous equation $\left(\delta^{15} \mathrm{~N}_{\text {basel }}=8.46 \%\right.$ and $\left.\lambda=1\right)$. Phytoplankton was considered as base $2\left(\delta^{15} \mathrm{~N}_{\text {base } 2}=\right.$ 8.02\%) (Amezcua et al. 2015).

The blotched stingray trophic niche breadth, estimated according to stomach content, was evaluated using Levin's standardized index, Bi (Krebs 2014), which ranges from 0 to 1 , with low values $(<0.6)$ indicating a specialist predator, and high values $(>0.6)$ indicating a generalist predator (Labropoulou and Eleftheriou 1997). The equation for Levin's standardized index for predator $j$ is as follows:

$$
B i=\frac{1}{n-1\left\{\left(\frac{1}{\sum P_{j i}^{2}}\right)-1\right\}}
$$

where $\Sigma P^{2}$ is the numerical proportion of the $j^{\text {th }}$ prey item in predator $i$ 's diet and $n$ is the number of prey categories. 


\section{RESULTS}

In total, 423 specimens of blotched stingray, Urotrygon chilensis, were collected, of which 211 were males and 212 were females. The captured stingrays ranged from 6.3 to $47.3 \mathrm{~cm}$ in total length (TL). In the north (Sinaloa), total length ranged from 13.4 to $39.3 \mathrm{~cm}$ (mean: $26.3 \mathrm{~cm} ; n=$ 59), and in the south (Michoacan and Guerrero) from 6.3 $\mathrm{cm}$ to $47.3 \mathrm{~cm}$ (mean: $26.8 \mathrm{~cm} ; n=364$ ).

Overall, 15 prey groups were identified (Table 1). The majority of prey items were crustaceans followed by fishes and molluscs. In Michoacan and Sinaloa 11 groups were observed, and 12 Guerrero.

Sample size was sufficient to describe the species diet with precision, as the species accumulation curve reached an asymptote at 12 in Guerrero, and 11 in Michoacan and Sinaloa respectively. These values were close but lower to the $S_{\max }$ value estimated with the Michaelis-Menten model, which were 14, 13, and 12 in Guerrero, Michoacan, and Sinaloa, respectively (Fig. 2).

Multivariate analyses indicated that the diet differed between localities, but not according to sex, season, or year. The nMDS plot showed two clear-cut groups according to the region (stress $=0.01$ ); the diet in Sinaloa was different from the diet in Michoacan and Guerrero, but the diet between the two southern regions was not different between each other (Fig. 3). The ANOSIM analysis confirmed that the diets between north and south regions differed significantly (Global R: 0.999, $P<0.05$ ), and the pairwise comparisons indicated that the diet differed between the north and the south (GuerreroSinaloa R: 0.945, $P<0.01$; Michoacan-Sinaloa R: 0.893, $P<0.01)$. No differences were found between the diet in the two southern zones (Guerrero-Michoacan R: 0.039, $P>0.05)$.

SIMPER indicated that the prey items more responsible for discrimination between north (Sinaloa) and south (Michoacan and Guerrero) were copepods, cladocerans, ostracods, and other small crustaceans which were consumed consistently in the north, whilst in the south the prey items consumed more consistently were crabs, prawns, shrimp and fish (Table 2).

Regarding the other factors analysed (sex, year, and season), ANOSIM analyses confirmed that the diets between these did not differ significantly (sex global $\mathrm{R}=$ $0.019, P>0.05$; year global $\mathrm{R}=0.053, P>0.05$; climatic seasons global $\mathrm{R}=0.032, P>0.05)$. Since differences were not found, SIMPER analyses were not performed.

Based on the results from the multivariate analyses, the stomach content data was divided into 2 groups: the north comprising organisms from Sinaloa, and the south, comprising organisms from Michoacan and Guerrero, because differences were found regarding these factors only. The percentage of empty stomachs was $58.6 \%$ for all data pooled, and showed regional differences, as the north area had $86.4 \%$ of full stomachs, while the south had $54.1 \%$ of full stomachs.

The infaunal crustaceans Peracarida and Cladocera were the most important food groups in the north area, representing a $38.4 \%$ and $29.3 \%$ of the $\%$ IRI respectively, followed by the polychaetes $\% \mathrm{IRI}=22.7$. In the south, the main prey item were shrimps; both in Michoacan and Guerrero the shrimps represented approximately $60 \%$ of the \%IRI (64.6 and 58.3 respectively), followed by the polychaetes which were also important for the diet of the blotched stingray in the south also (\%IRI Michoacan: 32.4, \%IRI Guerrero: 23.3) (Table 1, Fig. 4).

The differences found between areas, based on the main prey categories (infaunal crustaceans in the north versus shrimps in the south) was consistent according to the Morisita-Horn index, that showed no significant overlap between areas $(C \lambda=0.33)$.

The estimated trophic position for the blotched stingray using SCA was 3.51 in the north area and 3.56 in the south area. With SIA, the mean isotopic value of $\delta^{13} \mathrm{C}$ was $-14.03(\mathrm{SD}=0.5)$, and the mean value of $\delta^{15} \mathrm{~N}$ was $15.8(\mathrm{SD}=0.8)$. The estimated $T_{\mathrm{p}}$ was $4.05 \pm 0.21$ for the North and $4.52 \pm 0.58$, for the South. These results indicate that it is a mesopredator in soft bottom communities, and depending on the result, it can be placed in the middle or at the top of the food web.

According to the Levin's index, the range of the trophic niche breadth for the blotched stingray was 0.059 and 0.039 , at the north and south areas, respectively, which indicates that it is a specialist predator in both areas.

\section{DISCUSSION}

The presently reported study is the first to describe in detail the diet of the blotched stingray, Urotrygon chilensis, a species that is caught as bycatch and is recently becoming an important food resource in the Mexican Pacific (Navarro-García et al. 2004). Therefore, understanding its trophic habits is essential to acquire an EBFM in this area.

The blotched stingray is a demersal species known for its bentho-pelagic feeding habits (Kobelkowsky 2010), similar to other batoid species (Wilga and Motta 1998, Summers 2000). The position and form of its mouth allows it to consume benthic organisms as this is ventral and subterminal, with teeth arranged as crushing plates. All the prey items found are benthic organisms or demersal fish species, which were consumed probably when preying on benthic organisms as well.

The number and type of prey items encountered in the stomach of the blotched stingray indicates that it is an omnivore species (i.e., prey from more than one trophic level; Begon et al. 2006), with the ability to prey on different organisms inhabiting the benthic zone. However, the Levin's index shows that this species is a specialist predator, having a primary prey item, while being able to feed on other species if necessary. This is corroborated by the fact that in both zones they have a preferred prey item and that this is different in every zone; the infaunal crustaceans were their primary prey item in the north and the shrimp in the south. Feeding studies in similar species indicate that the main prey items of rays are benthic crustaceans, polychaetes, and molluscs (Amezcua-Linares 1996, Platell and Potter 1998, Valadez-González et al. 2001, Pasian Lonardoni et al. 2006, Collins et al. 2007). 
Table 1

Prey items of Urotrygon chilensis in the different regions of the Mexican Pacific

\begin{tabular}{|c|c|c|c|c|c|c|c|c|c|c|c|c|c|c|c|}
\hline \multirow[b]{4}{*}{ Bryozoa } & \multirow{2}{*}{\multicolumn{5}{|c|}{$\begin{array}{c}\text { North } \\
\text { Sinaloa }\end{array}$}} & \multicolumn{10}{|c|}{ South } \\
\hline & & & & & & \multicolumn{5}{|c|}{ Michoacan } & \multicolumn{5}{|c|}{ Guerrero } \\
\hline & \multirow{2}{*}{$\begin{array}{r}\% N \\
0\end{array}$} & \multirow{2}{*}{$\begin{array}{r}\% F \\
0\end{array}$} & \multirow{2}{*}{$\begin{array}{r}\% W \\
0\end{array}$} & \multicolumn{2}{|c|}{$\overline{\text { IRI \%IRI }}$} & \multirow{2}{*}{$\begin{array}{r}\% N \\
0\end{array}$} & \multirow{2}{*}{$\begin{array}{r}\% F \\
0\end{array}$} & \multirow{2}{*}{$\begin{array}{r}\% W W \\
0\end{array}$} & \multicolumn{2}{|c|}{$\overline{\text { IRI \%IRI }}$} & \multirow{2}{*}{$\begin{aligned} \% N \\
0.1\end{aligned}$} & \multirow{2}{*}{$\begin{array}{c}\% F \\
0.0\end{array}$} & \multirow{2}{*}{$\begin{array}{l}\% W \\
11.9\end{array}$} & \multicolumn{2}{|c|}{ IRI \%IRI } \\
\hline & & & & 0 & 0 & & & & 0 & 0 & & & & 2.0 & 0.0 \\
\hline Reptant molluscs & 3.3 & 15.3 & 1.0 & 66.6 & 1.5 & 0.1 & 0.1 & 0.1 & 0.02 & 0 & 0.2 & 0.4 & 2.1 & 1.1 & 0.0 \\
\hline Mollusca & 3.3 & 15.3 & 1.0 & 66.6 & & 0 & 0 & 0 & 0 & & 0 & 0 & 0 & 0 & \\
\hline Gastropoda & 0 & 0 & 0 & 0 & & 0 & 0 & 0 & 0 & & 0.1 & 0.0 & 1.4 & 0.1 & \\
\hline Bivalvia & 0 & 0 & 0 & 0 & & 0 & 0 & 0 & 0 & & 0.1 & 0.4 & 0.7 & 0.3 & \\
\hline Reptant polychaeta & 7.0 & 15.8 & 58.11 & 1030.4 & 22.7 & 40.7 & 34.7 & 28.9 & 2179.1 & 32.4 & 44.0 & 21.4 & 14.6 & 956.8 & 23.3 \\
\hline Polychaeta & 7.0 & 15.8 & 58.11 & 1030.4 & & 0 & 0 & 0 & 0 & & 44.0 & 21.4 & 14.6 & 956.8 & \\
\hline Exogone sp. & 0 & 0 & 0 & 0 & & 40.7 & 34.7 & 28.9 & 2179.1 & & 0 & 0 & 0 & 0 & \\
\hline Ostracods & 7.1 & 14.8 & 4.2 & 166.3 & 3.7 & 0 & 0 & 0 & 0 & 0 & 0 & 0 & 0 & 0 & 0 \\
\hline Copepods & 5.5 & 8.7 & 2.9 & 72.5 & 1.6 & 0 & 0 & 0 & 0 & 0 & 0 & 0 & 0 & 0 & 0 \\
\hline Cladocerans & 46.5 & 19.2 & 22.51 & 1326.4 & 29.3 & 0 & 0 & 0 & 0 & 0 & 0 & 0 & 0 & 0 & 0 \\
\hline Peracarida & 22.2 & 57.9 & 7.91 & 1739.6 & 38.4 & 9.2 & 1.1 & 11.1 & 114.3 & 1.7 & 7.8 & 3.7 & 23.1 & 262.9 & 6.4 \\
\hline Amphipoda & 10.3 & 23.5 & 2.5 & 301.4 & & 5.8 & 0.3 & 6.7 & 40.9 & & 4.1 & 0.9 & 12.6 & 62.8 & \\
\hline Isopoda & 4.0 & 10.3 & 1.5 & 56.1 & & 1.0 & 0.4 & 2.2 & 3.1 & & 0.6 & 1.9 & 2.1 & 5.2 & \\
\hline Cumacea & 0 & 0 & 0 & 0 & & 2.4 & 0.4 & 2.2 & 6.2 & & 2.0 & 0.5 & 4.3 & 10.5 & \\
\hline Tanaidacea & 0 & 0 & 0 & 0 & & 0 & 0 & 0 & 0 & & 0.4 & 0.1 & 3.5 & 1.6 & \\
\hline Mysidacea & 7.8 & 24.1 & 4.0 & 283.8 & & 0 & 0 & 0 & 0 & & 0.8 & 0.2 & 0.5 & 0.5 & \\
\hline Eucarida & 2.5 & 12.7 & 1.7 & 53.4 & 1.2 & 0.5 & 0.3 & 2.2 & 1.8 & 0 & 0.3 & 1.2 & 2.8 & 4.1 & 0.1 \\
\hline Euphausiacea & 2.5 & 12.7 & 1.7 & 53.4 & & 0 & 0 & 0 & 0 & & 0 & 0 & 0 & 0 & \\
\hline Stomatopoda & 0 & 0 & 0 & 0 & & 0 & 0 & 0 & 0 & & 0.3 & 1.2 & 2.8 & 4.1 & \\
\hline Squilla sp. & 0 & 0 & 0 & 0 & & 0.5 & 0.3 & 2.2 & 1.8 & & 0 & 0 & 0 & 0 & \\
\hline $\begin{array}{l}\text { Unidentified } \\
\text { Decapoda }\end{array}$ & 0.1 & 0.1 & 0.1 & 0.02 & 0 & 0.1 & 0.1 & 0.1 & 0.02 & 0 & 0.1 & 0.0 & 0.7 & 0.1 & 0.0 \\
\hline Shrimps & 2.6 & 9.6 & 3.6 & 60.0 & 1.3 & 34.7 & 58.3 & 46.7 & 4343.1 & 64.6 & 32.1 & 52.5 & 28.3 & 2398.5 & 58.3 \\
\hline Penaeidae & 2.6 & 9.6 & 3.6 & 60.0 & & 34.7 & 58.3 & 46.7 & 4343.1 & & 32.1 & 52.5 & 28.3 & 2398.5 & \\
\hline Crabs and lobsters & 0 & 0 & 0 & 0 & 0 & 13.6 & 5.3 & 4.4 & 83.2 & 1.2 & 12.6 & 8.7 & 18.8 & 400.4 & 9.7 \\
\hline Caridea & 0 & 0 & 0 & 0 & & 0 & 0 & 0 & 0 & & 0.1 & 0.0 & 0.7 & 0.1 & \\
\hline Anomura & 0 & 0 & 0 & 0 & & 0 & 0 & 0 & 0 & & 0.1 & 0.6 & 0.7 & 0.5 & \\
\hline Thalassinidea & 0 & 0 & 0 & 0 & & 0 & 0 & 0 & 0 & & 0.5 & 2.6 & 1.4 & 4.2 & \\
\hline Brachyura & 0 & 0 & 0 & 0 & & 0 & 0 & 0 & 0 & & 6.2 & 2.6 & 7.8 & 68.1 & \\
\hline Megalopa larvae & 0 & 0 & 0 & 0 & & 6.9 & 3.5 & 2.2 & 22.9 & & 4.7 & 1.9 & 6.6 & 43.8 & \\
\hline Raninidae & 0 & 0 & 0 & 0 & & 0 & 0 & 0 & 0 & & 0.8 & 0.7 & 1.1 & 1.7 & \\
\hline Portunidae & 0 & 0 & 0 & 0 & & 0 & 0 & 0 & 0 & & 0.1 & 0.3 & 0.6 & 0.2 & \\
\hline Leucosiidae & 0 & 0 & 0 & 0 & & 6.7 & 1.8 & 2.2 & 18.7 & & 0 & 0 & 0 & 0 & \\
\hline $\begin{array}{l}\text { Unidentified } \\
\text { crustaceans }\end{array}$ & 0 & 0 & 0 & 0 & 0 & 0.1 & 0.1 & 0.1 & 0.02 & 0 & 0.1 & 2.2 & 0.7 & 1.5 & 0.0 \\
\hline $\begin{array}{l}\text { Brittle star } \\
\text { (Ophiuroids) }\end{array}$ & 0.1 & 0.1 & 0.1 & 0.02 & 0 & 0.1 & 0.1 & 0.1 & 0.02 & & 0.1 & 0.0 & 3.9 & 0.2 & 0.0 \\
\hline Fish & 1.7 & 9.4 & 0.3 & 18.6 & 0.3 & 1.1 & 0.2 & 4.4 & 5.7 & 0.1 & 2.2 & 9.7 & 7.1 & 84.0 & 2.0 \\
\hline Teleostomi & 0 & 0 & 0 & 0 & & 0 & 0 & 0 & 0 & & 0.1 & 3.4 & 1.2 & 4.4 & \\
\hline Perciformes & 0 & 0 & 0 & 0 & & 0 & 0 & 0 & 0 & & 2.0 & 6.2 & 5.3 & 43.1 & \\
\hline Pleuronectiformes & 0 & 0 & 0 & 0 & & 0 & 0 & 0 & 0 & & 0.1 & 0.1 & 0.6 & 0.1 & \\
\hline Cynoglossidae & 0 & 0 & 0 & 0 & & 1.1 & 0.2 & 4.4 & 5.7 & & 0 & 0 & 0 & 0 & \\
\hline Fish remains & 1.7 & 9.4 & 0.3 & 18.6 & & 0 & 0 & 0 & 0 & & 0 & 0 & 0 & 0 & \\
\hline Organic Matter & 0 & 0 & 0 & 0 & 0 & 0.1 & 0.0 & 2.2 & 0.3 & 0.0 & 0.1 & 0.1 & 0.1 & 0.02 & 0 \\
\hline
\end{tabular}

$\% N=$ percentage of abundance, $\% W=$ percentage of biomass, $\% F=$ percentage of occurrence, IRI = index of relative importance. 
The differences observed in the diet of the blotched stingray in the two areas analysed, according to the Morisita-Horn index, are likely to be related to spatial differences in the benthic community, probably as a consequence of different oceanographic characteristics, ecological factors, differential fishing practices in these zones, etc. The north zone is more than $600 \mathrm{~km}$ away
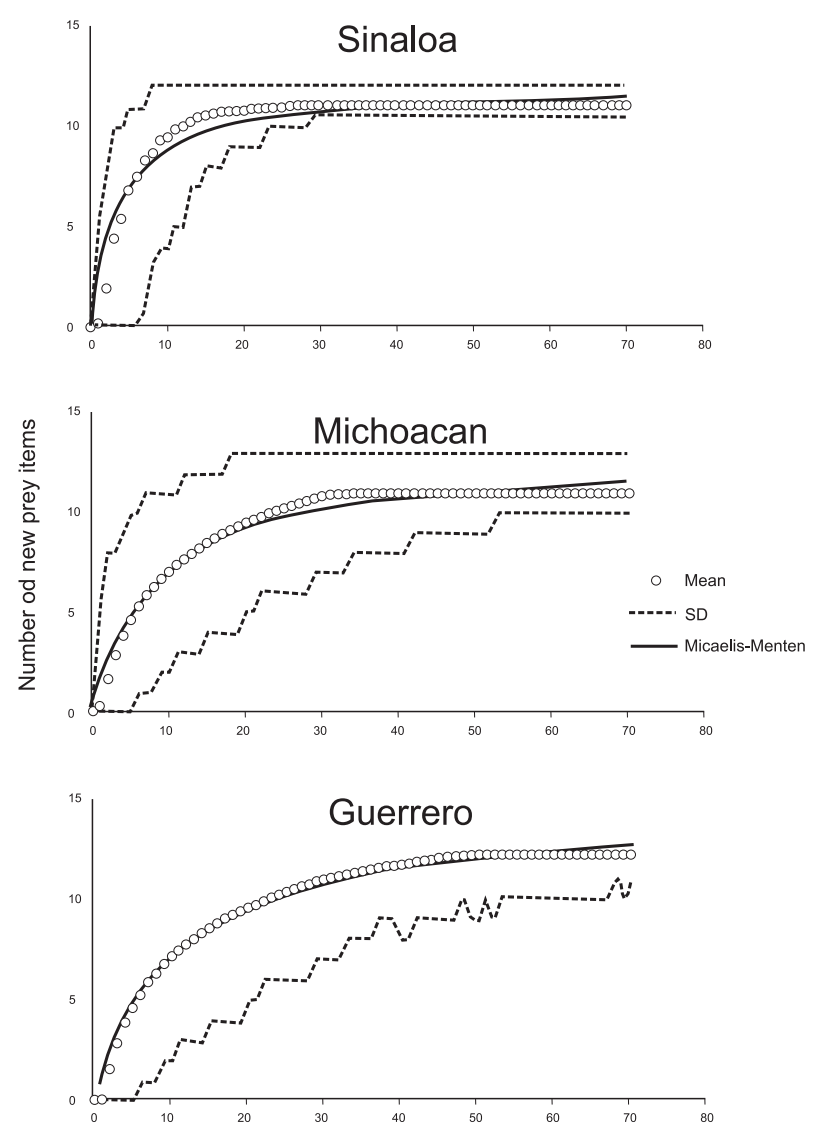

No. of stomachs

Fig. 2. Prey items accumulation curve and MichaelisMenten model for Urotrygon chilensis in the 3 sampled regions of the Mexican Pacific
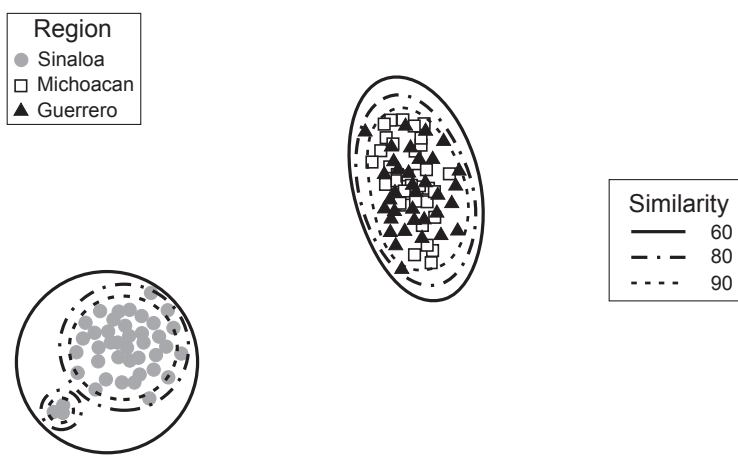

Fig. 3. Non-metric multidimensional scaling plot of the diet of Urotrygon chilensis in the different sampled regions of the Mexican Pacific; The circles indicate percentage similarity according to Bray-Curtis similarity coefficient from the south zone, and consists of a diverse mosaic of mangroves, intertidal flats, freshwater marshes, extensive brackish areas, and emerging brackish marshes. The specific area where the organisms were captured is characterized by coastal wetlands, coastal lagoons, and estuaries, with high seasonal variability and exceptionally high primary productivity. This causes abrupt changes

Table 2

Mean pairwise abundance of important prey items in the different zones based on similarity of percentages analysis (SIMPER)

\begin{tabular}{|c|c|c|c|c|}
\hline \multirow{2}{*}{ Food item } & \multicolumn{2}{|c|}{$\begin{array}{c}\text { Mean } \\
\text { abundance }\end{array}$} & \multirow{2}{*}{$\begin{array}{l}\text { Mean } \\
\text { dissimi- } \\
\text { larity }\end{array}$} & \multirow{2}{*}{$\begin{array}{c}\mathrm{MD} / \\
\mathrm{SD}\end{array}$} \\
\hline & North & South & & \\
\hline Fishes & 1.12 & 41.73 & 6.52 & $\underline{7.28}$ \\
\hline Shrimps & 0.23 & 7.38 & 4.62 & $\underline{7.05}$ \\
\hline Reptant mollusks & 41.07 & 32.33 & 7.73 & 1.62 \\
\hline Eucarida & 9.58 & 0.00 & 3.08 & $\underline{2.46}$ \\
\hline Peracarida & 7.32 & 0.00 & 2.37 & $\underline{2.55}$ \\
\hline Cladocerans & 34.42 & 0.00 & 11.7 & $\underline{2.08}$ \\
\hline Unidentified Decapoda & 6.36 & 57.08 & 16.74 & $\underline{\mathbf{3 . 3 5}}$ \\
\hline Phyllum Bryozoa & 4.67 & 2.49 & 1.25 & 1.44 \\
\hline $\begin{array}{l}\text { Crabs, prawns and } \\
\text { lobsters }\end{array}$ & 0.00 & 10.25 & 3.19 & 1.96 \\
\hline Ostracoda & 13.93 & 0.09 & 3.26 & $\underline{2.46}$ \\
\hline Copepoda & 6.74 & 2.13 & 1.59 & $\underline{1.99}$ \\
\hline Reptant Polychaeta & 14.57 & 12.93 & 0.33 & 0.78 \\
\hline Unidentified crustaceans & 6.35 & 0.00 & 1.98 & 1.53 \\
\hline
\end{tabular}

North $=$ Sinaloa, South $=$ Michoacan and Guerrero; $\mathrm{MD} / \mathrm{SD}=$ mean dissimilarity/standard deviation; Bold and underlined values represent those species with highest mean dissimilarity divided by the standard deviation between pairs of prey items.

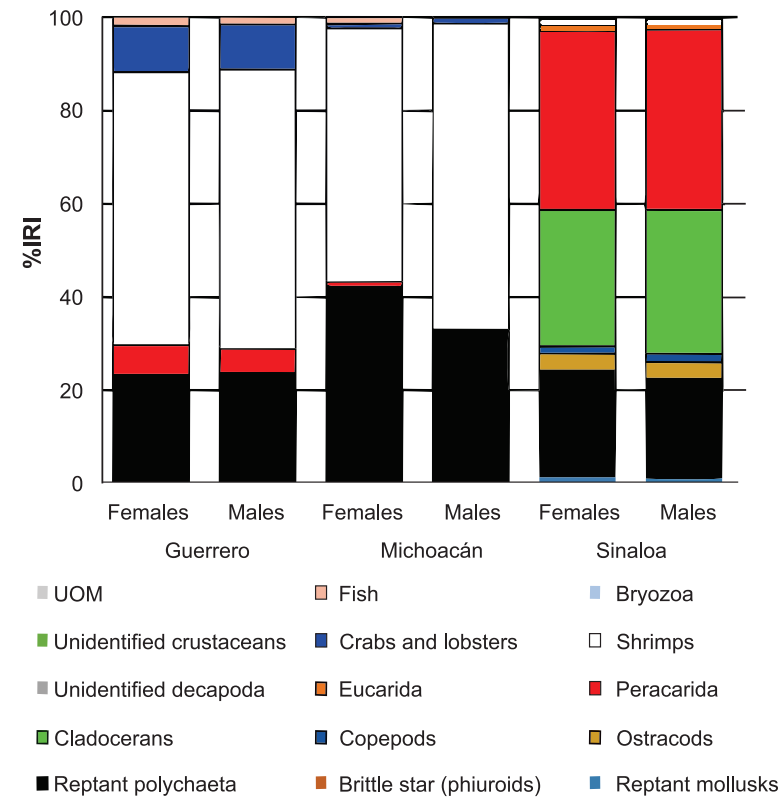

Fig. 4. Plot of \% IRI of the main prey groups found in female and male Urotrygon chilensis in the studied regions of the Mexican Pacific 
in salinity, with silt-clay sediments and mud dominating the system (Flores-Verdugo et al. 1990). This area is also characterized by the presence of the largest shrimp fleet in the Mexican Pacific, as well as by the presence of a large community of small scale fishers that also catch shrimp and fin fish with small trawls on board skiffs (more than 11000 skiffs, and more than 500 fishing boats were registered during the 2013 fishing season); the principal shrimp landings of Mexico come from this area (Anonymous 2013).

In comparison, the south area is characterized by a narrow and steep continental shelf with rocky bottoms whose flanks descend steeply. In general, the sediments are thick near the coast, composed of sands with patches of gravel, boulders, and crags worn while in deeper parts it is common to find fine sands, silts, and clays. There is an abundance of lakes that cover large areas with steep coasts. On the slope there is a considerable amount of rivers flowing into the lagoon systems or directly into the Pacific Ocean (Amezcua-Linares 1996). Opposite to the north area, in this area there is little fishing activity, since trawling is difficult due to bottom topography. This is reflected in the number of large fishing boats (1) and skiffs (approximately 3000) operating in the area, which are much less than the numbers found in the north.

Our results show that in the north area, where there is a high fishing pressure for shrimp mainly, but also for other demersal fish species in the coastal zone (Anonymous 2013), the blotched stingray preys mainly on infaunal crustaceans such as cladocerans, ostracods, copepods, etc.

However, in the south, there is a narrow continental shelf, so trawl fisheries are scarce, and therefore the fishing pressure is much less, and this allows the development of species associated with the bottom, such as Penaeidae shrimps, and therefore the abundance of benthic predators increase, such as demersal fish (Gunter 1961, Omori 1975). In this area, the blotched stingray preys mainly on shrimp. These results were confirmed by SIMPER, which indicates that the above-mentioned species are the responsible for the differences found between zones. Thus, the differences in oceanographic conditions between the two areas, the potential prey species that are distributed in them, as well as human activities, could influence the difference in the trophic spectrum found in the blotched stingray, indicating that it can change its diet and adapt to prey on the available resources in the area.

The lack of differences between sex, season, and year indicate that, at least during the duration of our study, the availability and types of prey remained the same in the different areas during the length of the study. It is possible that differences might have occurred according to size classes. Unfortunately, this analysis could not be performed because in the majority of the samples obtained from the commercial catch, the value of the length was missing, and only size intervals were available, and these were not standardized. Therefore a meaningful analysis could not be undertaken. This was a serious limitation for this study, as the stomachs were obtained when the fishers were gutting the organisms prior to being commercialized, and only the sex could be obtained. However it was possible to analyse the diet in a spatiotemporal scale.

The estimated $T_{\mathrm{p}}$ values estimated with SCA were 3.51 in the north and 3.56 in the south, so the variations are negligible, and according to the TROPH method there would not be any differences in the $T_{\mathrm{p}}$ of this species in both zones. However, using the SIA, the estimated $T_{\mathrm{p}}$ was 4.0 in the north and 4.52 in the south. These values seem to be more accurate, as the lesser $T_{\mathrm{p}}$ value estimated with SIA was found in the north part, where the blotched stingray preys mainly on infaunal crustaceans, whilst in the south, where it preys on larger crustaceans, which are also benthic predators, the $T_{\mathrm{p}}$ is higher. Amezcua et al. (2015) demonstrated that the SCA tends to underestimate the $T_{\mathrm{p}}$ value, and that the results also depend on the assumed $T_{\mathrm{p}}$ of the prey species, which it is usually unknown. Considering this, it can be concluded that the botched stingray is a third order omnivore consumer since it feeds on prey items from different $T_{\mathrm{p}}$. Also, depending on the availability and type of prey in the area, it can be positioned as a top predator in the ecosystem, which was already reported by Yáñez-Arancibia and AmezcuaLinares (1979). This means that this species can occupy a different $T_{\mathrm{p}}$ in the system depending on the available prey, although it is at the top of the trophic pyramid.

Also, the SIA allowed us to corroborate the feeding habits of this species, as the $\delta^{13} \mathrm{C}$ and $\delta^{15} \mathrm{~N}$ values were similar to that of other predators that consume benthic species; for example, a typical benthic species such as the scalloped hammerhead shark, Sphyrna lewini (Griffith et Smith, 1834), have values similar to those of the blotched stingray $\left(\delta^{15} \mathrm{~N}\right.$ values from $18.67 \%$ to $19.72 \%, \delta^{13} \mathrm{C}$ values from $-15.06 \%$ to $-14.79 \%$ for the hammerhead shark) (Torres Rojas et al. 2014). Typical pelagic predators such as the blue marlin, Makaira nigricans Lacepède, 1802 , usually present lower $\delta^{15} \mathrm{~N}(15.28 \%$ to $16.60 \%$ o) and $\delta^{13} \mathrm{C}(-17.33 \%$ to $-16.05 \%$ o values than a benthic predator (Torres Rojas et al. 2014). The fact that benthic crustaceans were the species that most contributed to the diet of the blotched stingray, together with the results from the Levin's index, support the conclusion that this species is a coastal benthic predator.

Understanding trophic position is important for defining the position of various species within the food web (Bakhoum 2007). The trophic position of the blotched stingray determined by our study was 3.5 , indicating that this species is a secondary predator in the north and south regions. Trophic levels for other batoid species have been found quite high by Ebert and Bizzarro (2007) who reported values between 3.52 and 4.15, however, none of the species evaluated were part of the family Urotrygonidae. Jacobsen and Bennett (2013) recently found that species of the family Urotrygonidae have a mean trophic level of 3.52, which is similar to the trophic level found in both study areas of this work. All of these results indicate that the family Urotrygonidae consists only of secondary predators.

In order to achieve an EBFM in the Gulf of California, it is necessary to continue with these types of studies 
for the other species inhabiting the area, in addition to monitoring fisheries landings, fishing effort, and variations in biotic and abiotic factors in the area over a long period. However, this study is a step towards reaching the ultimate goal of sustainable exploitation of marine resources on an ecosystem approach.

\section{ACKNOWLEDGMENTS}

We thank C. Suarez and G. Ramirez for editing the figures. This work was supported by the research project PAPIIT-IN217408-3. A.L. Castellanos-Cendales thanks CONACYT for the MSc grant.

\section{REFERENCES}

Amezcua F., Muro-Torres V., Soto-Jiménez M.F. 2015. Stable isotope analysis versus TROPH: A comparison of methods for estimating fish trophic positions in a subtropical estuarine system. Aquatic Ecology 49 (2): 235-250.

DOI: $\underline{10.1007 / \mathrm{s} 10452-015-9517-4}$

Amezcua-Linares F. 1996. Peces demersales de la plataforma continental del Pacífico Central de México. Instituto de Ciencias del Mar y Limnología, UNAM, México.

Andrew N.L., Pepperell J.G. 1992. The by-catch of shrimp trawl fisheries. Oceanography and Marine Biology Annual Review 30: 527-565.

Anonymous 2013. Anuario estadístico de Acuacultura y Pesca 2013. Comisión Nacional de Acuacultura y Pesca, SAGARPA, Mazatlán, Mexico.

Bakhoum S.A. 2007. Diet overlap of immigrant narrowbarred Spanish mackerel Scomberomorus commerson (Lac., 1802) and the largehead hairtail ribbonfish Trichiurus lepturus (L., 1758) in the Egyptian Mediterranean coast. Animal Biodiversity and Conservation 30 (2): 147-160.

Begon M., Townsend C.R., Harper J.L. 2006. Ecology: From individuals to ecosystems. 4th edn. Blackwell Publishing, Malden, MA, USA, Oxford, UK, Carlton, Victoria, Australia.

Benke A.C., Wallace J.B., Harrison J.W., Koebel J.W. 2001. Food web quantification using secondary production analysis: Predaceous invertebrates of the snag habitat in a subtropical river. Freshwater Biology 46 (3): 329-346. DOI: $10.1046 / \mathrm{j} .1365-2427.2001 .00680 . \mathrm{x}$

Bethea D.M., Buckel J.A., Carlson J.K. 2004. Foraging ecology of the early life stages of four sympatric shark species. Marine Ecology Progress Series 268: 245264.

DOI: $\underline{10.3354 / \operatorname{meps} 268245}$

Bizzarro J.J., Robinson H.J., Rinewalt C.S., Ebert D.A. 2007. Comparative feeding ecology of four sympatric skate species off central California, USA. Environmental Biology of Fishes 80 (2-3): 197-220. DOI: $\underline{10.1007 / \mathrm{s} 10641-007-9241-6}$

Bonfil R. 1994. Overview of world elasmobranch fisheries. FAO, Rome.
Bonfil R. 1997. Status of shark resources in the southern Gulf of Mexico and Caribbean. Implications for management. Fisheries Research 29 (2): 101-117. DOI: $10.1016 / \mathrm{S} 0165-7836(96) 00536-\mathrm{X}$

Branch T.A., Watson R., Fulton E.A., Jennings S., McGilliard C.R., Pablico G.T., Ricard D., Tracey S.R. 2010. The trophic fingerprint of marine fisheries. Nature 468 (7322): 431-435. DOI: $10.1038 /$ nature 09528

Cailliet G.M., Love M., Ebeling A. 1986. Fishes: A field and laboratory manual on their structure, identification and history. Waveland Press, Long Grove, IL, USA.

Clark J.S., Carpenter S.R., Barber M., Collins S., Dobson A., Foley J.A., Lodge D.M., Pascual M., Pielke R.jr., Pizer W., Pringle C., Reid W.V., Rose K.A., Sala O., Schlesinger W.H., Wall D.H., Wear D. 2001. Ecological forecasts: An emerging imperative. Science 293 (5530): 657-660. DOI: $10.1126 /$ science.293.5530.657

Clarke K.R., Warwick R.M. 2001. Change in marine communities: An approach to statistical analysis and interpretation. 2nd edn. PRIMER-E, Plymouth, UK.

Colléter M., Guitton J., Gascuel D. 2013. An Introduction to the EcoTroph R Package: Analyzing aquatic ecosystem trophic networks. The R Journal 5 (1): 98-107.

Collins A.B., Heupel M.R., Hueter R.E., Motta P.J. 2007. Hard prey specialists or opportunistic generalists? An examination of the diet of the cownose ray, Rhinoptera bonasus. Marine and Freshwater Research 58 (1): 135-144. DOI: $10.1071 / \mathrm{MF} 05227$

Compagno L.J.V., Krupp F., Schneider W. 1995. Tiburones. Pp. 647-1200. In: Fischer W., Krupp F., Schneider W., Sommer C., Carpenter K.E., Niem V.H. (eds.) Guía FAO para la identificación de especies para los fines de pesca Pacífico Centro-Oriental Vol II Vertebrados, Parte 1.

Cortés E. 1997. A critical review of methods of studying fish feeding based on analysis of stomach contents: Application to elasmobranch fishes. Canadian Journal of Fisheries and Aquatic Sciences 54 (3): 726-738. DOI: $10.1139 / \mathrm{f} 96-316$

Cortés E. 1999. Standardized diet compositions and trophic levels of sharks. ICES Journal of Marine Science: Journal du Conseil 56 (5): 707-717. DOI: $10.1006 /$ jmsc. 1999.0489

Dulvy N.K., Pardo S.A., Simpfendorfer C.A., Carlson J.K. 2014. Diagnosing the dangerous demography of manta rays using life history theory. PeerJ 2: e400. DOI: $10.7717 /$ peerj.400

Dulvy N.K., Reynolds J.D. 2002. Predicting extinction vulnerability in skates. Conservation Biology 16 (2): 440-450. DOI: $10.1046 / \mathrm{j} .1523-1739.2002 .00416 . x$

Ebert D.A., Bizzarro J.J. 2007. Standardized diet compositions and trophic levels of skates (Chondrichthyes: Rajiformes: Rajoidei). Environmental Biology of Fishes 80 (2): 221-237. 
DOI: $10.1007 / \mathrm{s} 10641-007-9227-4$

Ellis J.K., Musick J.A. 2007. Ontogenetic changes in the diet of the sandbar shark, Carcharhinus plumbeus, in lower Chesapeake Bay and Virginia (USA) coastal waters. Environmental Biology of Fishes 80 (1): 5167.

DOI: $10.1007 / \mathrm{s} 10641-006-9116-2$

Eschmeyer W.N., Fricke R., van der Laan R. (eds.) 2017. Catalog of fishes: Genera, species, references. California Academy of Sciences, San Francisco, USA. http://researcharchive.calacademy.org/ research/ichthyology/_catalog/fishcatmain.asp [Accessed on 28 June 2017.]

Escobar-Sánchez O., Abitia-Cárdenas L.A., GalvánMagaña F. 2006. Food habits of the Pacific angel shark Squatina californica in the southern Gulf of California, Mexico. Cybium 30 (4) Suppl.: 91-97.

Ferry L.A., Cailliet G.M. 1996. Sample size and data analysis: are we characterizing and comparing diet properly. Pp. 71-80. In: MacKinlay D., Shearer K. (eds.) Feeding ecology and nutrition in fish Proceedings of the Symposium on the Feeding Ecology and Nutrition in Fish. International Congress on the Biology of Fishes. American Fisheries Society.

Fischer J., Erikstein K., D’Offay B., Gubbisberg S., Barone M. 2012. Review of the implementation of the International Plan of Action for the conservation and management of sharks. FAO Fisheries and Aquaculture Circular No. 1076. FAO, Rome.

Fischer W., Krupp F., Schneider W., Sommer C., Carpenter K.E., Niem V.H. 1995. Guía FAO para la identificación de especies para los findes de pesca. Pacífico centro-oriental. FAO, Rome.

Flores-Ortega F.R., Godínez-Domínguez E., GonzálezSansón G., Rojo-Vázquez J.A., Corgos A., MoralesJáuregui M.Y. 2011. Feeding habits of the three round stingrays (Rajiformes: Urotrygonidae) in the central Mexican Pacific. Hábitos alimentarios de tres especies de raya (Rajiformes: Urotrygonidae) en el Pacífico central mexicano. Ciencias Marinas 37 (3): 279-292. DOI: $10.7773 / \mathrm{cm} . v 37 \mathrm{i} 3.1871$

Flores-Verdugo F., González-Farías F., RamírezFlores O., Amezcua-Linares F., Yáñez-Arancibia A., Alvarez-Rubio M., Day J.W. 1990. Mangrove ecology, aquatic primary productivity, and fish community dynamics in the Teacapán-Agua Brava Lagoon-Estuarine system (Mexican Pacific). Estuaries 13 (2): 219-230.

DOI: $\underline{10.2307 / 1351591}$

Gosner K.L. 1971. Guide to identification of marine and estuarine invertebrates. Wiley-Interscience, New York, NY, USA.

Gunter G. 1961. Habitat of juvenile shrimp (Family Penaeidae). Ecology 42 (3): 598-600. DOI: $10.2307 / 1932255$

Hendrickx M. 1995. Guía de la FAO para identificación de especies para los fines de la pesca. Pacífico centrooriental. Vol. I. Plantas e invertebrados. FAO, Rome.
Jacobsen I.P., Bennett M.B. 2012. Feeding ecology and dietary comparisons among three sympatric Neotrygon (Myliobatoidei: Dasyatidae) species. Journal of Fish Biology 80 (5): 1580-1594.

DOI: $10.1111 / \mathrm{j} .1095-8649.2011 .03169 . \mathrm{x}$

Jacobsen I.P., Bennett M.B. 2013. A comparative analysis of feeding and trophic level ecology in stingrays (Rajiformes; Myliobatoidei) and electric rays (Rajiformes: Torpedinoidei). PLoS One 8 (8): e71348. DOI: 10.1371/journal.pone.0071348

Kobelkowsky A. 2010. Anatomía comparada del sistema digestivo de las rayas Urotrygon chilensis y Dasyatis sabina (Myliobatiformes). Revista Chilena de Historia Natural 83 (3): 387-394. DOI: 10.4067/S0716$\underline{078 \times 2010000300006}$

Koen-Alonso M. 2007. [Chapter 1] A process-oriented approach to the multispecies functional response. Pp. $1-36$.

DOI: 10.1007/978-1-4020-5337-5_1 In: Rooney N., McCann K.S., Noakes D.L.G. (eds.) From energetics to ecosystems: The dynamics and structure of ecological systems. Springer Netherlands, Dordrecht, The Netherlands. DOI: $10.1007 / 978-1-4020-5337-5$

Krebs C.J. 2014. Ecological methodology. Addison Wesley Longman.

Labropoulou M., Eleftheriou A. 1997. The foraging ecology of two pairs of congeneric demersal fish species: Importance of morphological characteristics in prey selection. Journal of Fish Biology 50 (2): 324 340.

DOI: $10.1111 /$ j.1095-8649.1997.tb01361.x

Langton R.W. 1982. Diet overlap between Atlantic cod, Gadus morhua, silver hake, Merluccius bilinearis, and fifteen other Northwest Atlantic finfish. Fishery Bulletin 80 (4): 745-759.

Layman C.A., Winemiller K.O., Arrington D.A., Jepsen D.B. 2005. Body size and trophic position in a diverse tropical food web. Ecology 86 (9): 2530-2535. DOI: $10.1890 / 04-1098$

Levine S. 1980. Several measures of trophic structure applicable to complex food webs. Journal of Theoretical Biology 83 (2): 195-207.

DOI: $10.1016 / 0022-5193(80) 90288-X$

Mangel M., Levin P.S. 2005. Regime, phase and paradigm shifts: Making community ecology the basic science for fisheries. Philosophical Transactions of the Royal Society B: Biological Sciences 360 (1453): 95-105. DOI: $10.1098 /$ rstb.2004.1571

Marasco R.J., Goodman D., Grimes C.B., Lawson P.W., Punt A.E., Quinn II T.J. 2007. Ecosystem-based fisheries management: Some practical suggestions. Canadian Journal of Fisheries and Aquatic Sciences 64 (6): 928-939.

DOI: $\underline{10.1139 / \mathrm{f07}-062}$

Marshall A.D., Kyne P.M., Bennett M.B. 2008. Comparing the diet of two sympatric urolophid elasmobranchs (Trygonoptera testacea Müller \& Henle and Urolophus kapalensis Yearsley \& Last): 
Evidence of ontogenetic shifts and possible resource partitioning. Journal of Fish Biology 72 (4): 883-898. DOI: $10.1111 /$ j.1095-8649.2007.01762.x

McEachran J., Miyake T. 1986. Taxonomy of the stingray genus Urotrygon (Myliobatiformes: Urolophidae): Preliminary results based on external morphology. Pp. 291-302. In: Uyeno T., Arai R., Taniuchi T., Matsuura K. (eds.) Second International Conference on IndoPacific Fishes. Ichthyological Society of Japan.

McEachran J.D., Carvalho M.R.d. 2002. Batoid fishes. Pp. 508-589. In: Carpenter K.E. (ed.) The living marine resources of the Western Central Atlantic Vol 1 Introduction, mollusks, crustaceans, hagfishes, sharks, batoid fishes and chimaeras. FAO, Rome.

Navarro-García G., Pacheco-Aguilar R., BringasAlvarado L., Ortega-García J. 2004. Characterization of the lipid composition and natural antioxidants in the liver oil of Dasyatis brevis and Gymnura marmorata rays. Food Chemistry 87 (1): 89-96.

DOI: $10.1016 /$ j.foodchem.2003.10.023

Navarro-González J., Bohórquez-Herrera J., Navia A., Cruz-Escalona V. 2012. Composición trófica de batoideos en la plataforma continental frente a Nayarit y Sinaloa, México. Ciencias Marinas 38 (2): 347-362.

Nelson J.S. 1984. Fishes of the world. John Wiley and Sons, New York-Chichester-Brisbane-TorontoSingapore.

Omori M. 1975. The biology of pelagic shrimps in the ocean. Pp. 233-324, 249a, 251-262, 262a, 263-271, 271a, 271b, 274-283, 283a, 285, 285a, 287-289, 289a, 291-298, 298a, 298b, 301-324. In: Russell F.S., Yonge M. (eds.) Advances in Marine Biology Vol. 12. Academic Press.

DOI: $10.1016 / \mathrm{S} 0065-2881(08) 60459-9$

Pasian Lonardoni A., Goulart E., Fontes de Oliveira E., Fedatto Abelha M.C. 2006. Hábitos alimentares e sobreposição trófica das raias Potamotrygon falkneri e Potamotrygon motoro (Chondrichthyes, Potamotrygonidae) na planície alagável do alto rio Paraná, Brasil. [Feeding habits and trophic overlap of Potamotrygon falkneri and Potamotrygon motoro rays (Chondrichthyes, Potamotrygonidae) on the floodplain of the Upper Paraná River, Brazil.] Acta Scientiarum Biological Sciences 28 (3): 195-202. [In Portuguese.] DOI: $10.4025 /$ actascibiolsci.v28i3.208

Pauly D., Watson R. 2005. Background and interpretation of the 'Marine Trophic Index' as a measure of biodiversity. Philosophical Transactions of the Royal Society of London B: Biological Sciences 360 (1454): 415-423.

DOI: $10.1098 /$ rstb.2004.1597

Pinkas L., Oliphant M.S., Iverson I.L.K. 1971. Food habits of albacore, bluefin tuna, and bonito in California waters. Fish Bulletin 152: 1-106.

Platell M.E., Potter I.C. 1998. Distributions, size compositions and diets of two abundant benthic ambush-feeding teleosts in coastal waters of southwestern Australia. Journal of the Marine Biological Association of the United Kingdom 78 (2): 587-608.
DOI: $10.1017 / \mathrm{S} 0025315400041643$

Platell M.E., Potter I.C., Clarke K.R. 1998. Resource partitioning by four species of elasmobranchs (Batoidea: Urolophidae) in coastal waters of temperate Australia. Marine Biology 131 (4): 719-734. DOI: $10.1007 / \mathrm{s} 002270050363$

Post D.M. 2002. Using stable isotopes to estimate trophic position: Models, methods, and assumptions. Ecology 83 (3): 703-718.

DOI: 10.1890/0012-9658(2002)083[0703:USITET]2.0.CO;2

Pratt H.L.jr., Cassey J.G. 1990. Shark reproductive strategies as a limiting factor in directed fisheries with a review of Holden's method of estimating growthparameters. Pp. 97-109. In: Pratt L.H.jr., Gruber S.H., Taniuchi T. (eds.) Elasmobranchs as living resources: Advances in the biology, ecology, systematics, and the status of the fisheries. NOAA Technical Report NMFS 90, Washington DC, USA.

Preti A., Smith S.E., Ramón D.A. 2004. Diet differences in the thresher shark (Alopias vulpinus) during transition from a warm-water regime to a cool-water regime off California-Oregon, 1998-2000. California Cooperative Oceanic Fisheries Investigations 45: 118 125.

Quinn II T.J. 2003. Ruminations on the development and future of population dynamics models in fisheries. Natural Resource Modeling 16 (4): 341-392. DOI: $\underline{10.1111 / j .1939-7445.2003 . t b 00119 . \mathrm{x}}$

Rogers P.J., Huveneers C., Page B., Hamer D.J., Goldsworthy S.D., Mitchell J.G., Seuront L. 2012. A quantitative comparison of the diets of sympatric pelagic sharks in gulf and shelf ecosystems off southern Australia. ICES Journal of Marine Science: Journal du Conseil 69 (8): 1382-1393. DOI: 10.1093/ icesjms/fss 100

Salazar-Vallejo S.I., León J.A., Salaices H. 1988. Poliquetos (Annelida: Polychaeta) de México. Universidad Autónoma de Baja California Sur, UABCS, México.

Schram F.R. 1986. Crustacea. Oxford University Press, Oxford, UK.

Smale M.J., Cowley P.D. 1992. The feeding ecology of skates (Batoidea: Rajidae) off the Cape south coast, South Africa. South African Journal of Marine Science 12 (1): 823-834. DOI: $10.2989 / 02577619209504744$

Smith D., Johnson K.B. 1996. A guide to marine coastal plankton and marine invertebrate larvae. 2nd edn. Kendall-Hunt Publishing Company, Dubuque, IA, USA.

Smith E.P., Zaret T.M. 1982. Bias in estimating niche overlap. Ecology 63 (5): 1248-1253. DOI: $\underline{10.2307 / 1938851}$

Stevens J., Bonfil R., Dulvy N.K., Walker P.A. 2000. The effects of fishing on sharks, rays, and chimaeras (chondrichthyans), and the implications for marine ecosystems. ICES Journal of Marine Science: Journal du Conseil 57 (3): 476-494.

DOI: $\underline{10.1006 / \mathrm{jmsc} .2000 .0724}$ 
Summers A.P. 2000. Stiffening the stingray skeletonan investigation of durophagy in myliobatid stingrays (Chondrichthyes, Batoidea, Myliobatidae). Journal of Morphology 243 (2): 113-126.

DOI: 10.1002/(SICI)1097-4687(200002)243:2<113::AID-JMOR1>3.0.C0;2-A

Tillett B.J., Meekan M.G., Field I.C. 2014. Dietary overlap and partitioning among three sympatric carcharhinid sharks. Endangered Species Research 25 (3): 283-293.

DOI: $10.3354 /$ esr00615

Torres Rojas Y.E., Páez Osuna F., Hernández Herrera A., Galván Magaña F., Aguiñiga García S., Villalobos Ortíz H., Sampson L. 2014. Feeding grounds of juvenile scalloped hammerhead sharks (Sphyrna lewini) in the south-eastern Gulf of California. Hydrobiologia 726 (1): 81-94.

DOI: $10.1007 / \mathrm{s} 10750-013-1753-9$

Valadez-González C., Aguilar-Palomino B., HernándezVázquez S. 2001. Hábitos alimentarios de la raya Urobatis halleri (Cooper, 1863) (Chondrichthyes: Urolophidae) capturada en la plataforma continetal de Jalisco y Colima, México. Feeding habits of the round stingray Urobatis halleri (Cooper, 1863) (Chondrichthyes: Urolophidae) from the continental shelf of Jalisco and Colima, Mexico. Ciencias Marinas 27 (1): 91-104.
Werner E.E., Gilliam J.F. 1984. The ontogenetic niche and species interactions in size-structured populations. Annual Review of Ecology and Systematics 15 (1): 393-425.

DOI: 10.1146/annurev.es.15.110184.002141

Wetherbee B.M., Cortés E. 2004. Food consumption and feeding habits. Pp. 225-246. In: Carrier J.C., Musick J.A., Heithaus M.R. (eds.) Biology of sharks and their relatives. CRC Marine Biology Series, CRC Press, Boca Raton, FL, USA.

Wilga C.D., Motta P.J. 1998. Feeding mechanism of the Atlantic guitarfish Rhinobatos lentiginosus: Modulation of kinematic and motor activity. Journal of Experimental Biology 201 (23): 3167-3183.

Yáñez-Arancibia A., Amezcua-Linares F. 1979. Ecología de Urolophus jamaicensis (Cuvier) en Laguna de Términos. Un sistema estuarino del sur del Golfo de México. (Pisces: Urolophidae). Anales del Centro de Ciencias del Mar y Limnología - UNAM 6 (2): 123-136.

Received: 19 October 2016

Accepted: 7 April 2017

Published electronically: 30 June 2017 